\title{
WORKPLACE ROMANCE DAN PERANANNYA TERHADAP KEPUASAN PERNIKAHAN KARYAWAN
}

\author{
WORKPLACE ROMANCE AND ITS ROLE FOR EMPLOYEE MARITAL SATISFACTION
}

\author{
Oleh : \\ Fauziyyah Sholeha Tunnissa ${ }^{1}$ \\ Yus Nugraha ${ }^{2}$ \\ Anissa Lestari Kadiyono ${ }^{3}$
}

\begin{abstract}
Submitted: 01 April 2020

Revision: 11 April 2020

Accepted: 19 Mei 2020

This purpose of this study is to determine the impact of workplace romance on employee marital satisfaction. The location used for the study is in the Yayasan X. The study population are all of the employees at Yayasan X who had one workplace partner totaling 254 people. The sample in this study were 72 people. The sampling technique is simple random sampling. The scale used in this study is the workplace romance scale compiled by Khan, Jianguo, Usman, \& Ahmad (2017) and the Marriage Satisfaction Scale based on aspects of marriage satisfaction from Fowers \& Olson (1993). The data analysis technique is simple regression analysis. The results of data analysis show that there is an impact of workplace romance on marriage satisfaction. The influence of workplace romance on marriage satisfaction is $24.6 \%$, the remains was influenced by other factors.
\end{abstract}

Keywords: workplace romance; marital satisfaction; marriage of employees

\section{ABSTRAK}

Penelitian ini bertujuan untuk mengetahui pengaruh workplace romance terhadap kepuasan pernikahan karyawan. Lokasi yang digunakan untuk penelitian adalah Yayasan X. Populasi penelitian adalah seluruh karyawan di Yayasan X yang memiliki pasangan satu tempat kerja yang berjumlah 254 orang. Sampel dalam penelitian ini sebanyak 72 orang. Teknik sampling yang digunakan adalah sampling acak sederhana. Skala yang digunakan dalam penelitian ini yaitu skala workplace romance yang disusun oleh Khan, Jianguo, Usman, \& Ahmad (2017) dan Skala Kepuasan Pernikahan berdasarkan aspek-aspek kepuasan pernikahan dari Fowers \& Olson (1993). Teknik analisis data yang digunakan adalah analisis regresi sederhana. Hasil analisis data menunjukkan bahwa terdapat pengaruh workplace romance terhadap kepuasan pernikahan. Besar pengaruh workplace romance terhadap kepuasan pernikahan sebanyak $24.6 \%$, sisanya dipengaruhi oleh faktor lain.

Kata kunci: workplace romance; kepuasan pernikahan; pernikahan karyawan

\section{PENDAHULUAN}

Larangan untuk menikah dengan orang satu organisasi menjadi permasalahan tersendiri bagi beberapa karyawan. Karena, beberapa perusahaan seperti BUMN, BUMD dan Bank

\footnotetext{
${ }^{1}$ Fauziyyah Sholeha Tunnissa, Universitas Padjadjaran , fauziyyah.fs@gmail.com

${ }^{2}$ Yus Nugraha, Universitas Padjadjaran, yus.nugraha@unpad.ac.id

${ }^{3}$ Anissa Lestari Kadiyono, Universitas Padjadjaran, anissa.lestari@unpad.ac.id
} 
memberlakukan sebuah aturan dimana karyawan tidak boleh memiliki hubungan dengan sesama karyawan. Konsekuensi jika melakukan hal tersebut adalah pemutusan kerja (PHK).

Pada tahun 2003 Mahkamah Konstitusi mengeluarkan peraturan pada UU no. 13 tahun 2003 tentang Ketenagakerjaan pasal 153 ayat (1) butir (f) dimana adanya larangan melakukan pemutusan kerja (PHK) dengan alasan pekerja mempunyai pertalian darah dan atau ikatan perkawinan dengan pekerja lainnya di dalam satu perusahaan, kecuali telah diatur dalam perjanjian kerja, peraturan perusahaan atau perjanjian kerja sama (Undang-Undang Republik Indonesia no. 13 tahun 2003).

Ikatan pernikahan antara karyawan dapat disebut dengan workplace romance. Workplace romance didefinisikan sebagai hubungan yang saling bersambut dan komitmen antara dua anggota organisasi yang mungkin melibatkan ketertarikan dan aktivitas fisik (Khan, Jianguo, Usman, \& Ahmad, 2017). Terdapat beberapa faktor yang dapat mengembangkan workplace romance, seperti kedekatan (geografis yang sedang berlangsung, persyaratan kerja yang sedang berlangsung, kontak sesekali), motif, jenis hubungan, karakteristik kelompok kerja, intensitas pekerjaan (Quinn, 1977), pertemuan berulang, kesamaan sikap, penilaian kinerja, gairah, evaluasi karakteristik terbuka calon pasangan, sikap romansa di tempat kerja, budaya organisasi, otonomi kerja (Pierce, Byrne, \& Aguinis, 1996).

Beberapa perusahaan yang mengizinkan karyawan untuk memiliki pasangan satu tempat kerja dengan beberapa peraturan seperti tidak diperbolehkannya pasangan dalam satu unit atau satu wilayah kerja. Peraturan tersebut dibuat untuk menghindari permasalahan yang akan muncul masalah kedepannya, karena jika permasalahan muncul, maka manajemen perusahaan perlu turun tangan dalam menyelesaikan masalah tersebut dan hal itu dapat merusak moril kerja dan produktivitas perusahaan (Castañeda, 2016; Karsten, 2006; Powell, 2011; Sias, 2008).

Peraturan-peraturan tersebut tentu akan memengaruhi hubungan pasangan karyawan tersebut, seperti mereka harus menjalani hubungan long distance relationship (LDR) karena peraturan tidak memperbolehkan mereka bekerja satu wilayah, yang akan berdampak pada komunikasi, tanggung jawab akan peran dalam pernikahan, pengasuhan anak, hubungan seksual. Hal-hal tersebut merupakan aspek-aspek kepuasan pernikahan. Fowers \& Olson (1993) menyatakan bahwa hal-hal tersebut merupakan beberapa aspek dari kepuasan pernikahan. Kepuasan pernikahan ini mencakupi beberapa hal, yaitu personality Issues, communication, conflict resolution, financial management, leisure activities, sexual relationship, children and parenting, family and friends, equalitarian roles, religious orientation. Aspek-aspek ini tentu perlu diperhatikan bagi setiap pasangan, maka dari itu beberapa pasangan berusaha untuk selalu dekat dengan psangannya agar terpenuhinya aspekaspek kepuasan pernikahan.

Menurut Olson, DeFrain, \& Skogrand (2014) kepuasan pernikahan adalah perasaan yang bersifat subjektif dari pasangan suami istri mengenai kualitas pernikahannya secara menyeluruh. Kepuasan pernikahan ini sangat sulit diseimbangkan dengan kehidupan pekerjaan, sehingga terkadang seseorang perlu berkorban atau akan banyak konflik yang ditimbulkannya yang memiliki dampak kepuasan pernikahan (Abele \& Volmer, 2011; Ahmed, 2016). Organisasi dapat memadukan antara keluarga dan pekerjaan, keterpaduan tersebut dapat memungkinkan mereka untuk merasa puas dengan hubungan mereka dan meminimalkan konflik yang dapat terjadi (Berlato \& Correa, 2017; van Steenbergen, Kluwer, \& Karney, 2014). Diizinkannya oleh perusahaan untuk adanya workplace romance serta mendukung dengan sikap manajemen yang mempermudah bagi pasangan karyawan tentu akan berdampak balik bagi perusahaan (Pierce \& Aguinis, 2003). 
Perry-Jenkins, Repetti, \& Crouter (2000) menyatakan bahwa hubungan antara pekerjaan dan keluarga adalah dua arah, beberapa penelitian muncul untuk mengeksplorasi bagaimana keluarga membentuk perilaku di tempat kerja, seperti dampak sentuhan kasih sayang dari pasangan dapat bermanifestasi dalam bentuk relaksasi dan perasaan yang baik, menghilangkan perasaan negatif dan meningkatkan kualitas hubungan (Burleson, Trevathan, \& Todd, 2007; Debrot, Schoebi, Perrez, \& Horn, 2013; Koole, Tjew A Sin, \& Schneider, 2014).

Banyak hal yang dapat ditingkatkan dari karyawan yang memiliki pasangan satu tempat kerja dengan perusahaan mendukung adanya workplace romance seperti kepuasan terhadap pekerjaan, komitmen organisasi, kinerja, motivasi karyawan, memberikan energi bagi dirinya dan kelompok, meningkatkan motivasi, mendorong kreativitas dan inovasi, dapat meminimalisir konflik terkait dengan pekerjaan, dapat meningkatkan kerjasama dan komunikasi dalam tim, memperkaya hubungan personal, menstabilkan tenaga kerja (Khan, Jianguo, Abdul Hameed, Mushtaq, \& Usman, 2018; Khan et al., 2017; Mainiero, 1989; Ramteke, 2015; Rusbult, Martz, \& Agnew, 1998). Peningkatan tersebut bergantung pada keberhasilan hubungan karyawan tersebut (Khan et al., 2018; Ramteke, 2015).

Berdasarkan penelitian-penelitian di atas, maka peneliti tertarik untuk mengetahui apakah terdapat pengaruh workplace romance terhadap kepuasan pernikahan pada karyawan di Yayasan X. Adapun hipotesis penelitian adalah sebagai berikut terdapat pengaruh yang signifikan workplace romance terhadap kepuasan pernikahan. Penelitian ini diharapkan dapat memberikan sumbangsih penelitian khususnya di bidang psikologi organisasi dan psikologi pernikahan dan menambah referensi mengenai workplace romance serta pengaruhnya terhadap kepuasan pernikahan.

\section{METODE PENELITIAN Variabel Penelitian}

Metode yang digunakan dalam penelitian ini adalah kuantitatif. Desain yang digunakan adalah korelasional. Penelitian ini menggunakan dua jenis variabel, yaitu workplace romance sebagai variabel independen $(\mathrm{X})$ dan kepuasan pernikahan sebagai variabel dependen $(\mathrm{Y})$. Berikut merupakan definisi operasional tiap-tiap variabel

\section{Lokasi Penelitian}

Penelitian ini dilakukan di Yayasan $\mathrm{X}$. Yayasan yang bergerak dalam bidang pendidikan, dakwah, dan sosial. Yayasan ini sangat mendukung adanya workplace romance. Workplace romance yang terjadi di Yayasan ini melalui dua cara, yaitu proses ta'aruf, dimana ini terjadi pada dua orang karyawan yang pada awalnya tidak saling mengenal atau salah satu pihak tertarik pada lawan jenis dan meminta tolong kepada Murrobi untuk menyampaikan niat baik tersebut kepada orang yang dituju dan karyawan yang sudah bekerja terlebih dahulu di Yayasan, membawa serta pasangannya untuk bekerja di tempat yang sama. Seleksi calon karyawan yang dibawa oleh pasangannya, sama hal nya dengan calon karyawan yang lain. Hanya saja, jika banyak calon karyawan yang sesuai dengan kualifikasi dan hasil tes yang baik, maka yang memiliki pasangan di Yayasan yang didahulukan.

Yayasan $\mathrm{X}$ juga memberikan fasilitas seperti rumah dinas, makan, tempat penitipan anak (TPA), pendidikan bagi anak karyawan, pedidikan agama bagi anak karyawan, dan tunjangan. Berdasarkan hal tersebut, maka peneliti memilih Yayasan $\mathrm{X}$ sebagai lokasi penelitian untuk lebih menggambarkan pengaruh workplace romance terhadap kepuasan pernikahan dengan organisasi yang sangat mendukung adanya workplace romance. 


\section{Subjek Penelitian}

Populasi dalam penelitian ini adalah karyawan Yayasan $\mathrm{X}$ yang memiliki pasangan dalam satu tempat kerja yaitu sebanyak 254 orang. Berdasarkan perhitungan, maka jumlah sampel yang diambil sebanyak 72 orang, dengan menggunakan teknik sampling acak sederhana.

\section{Metode Pengumpulan Data dan Instrumen Penelitian}

Metode pengumpulan data pada penelitian ini menggunakan kuesioner. Instrumen yang digunakan pada penelitian ini adalah skala workplace romance, skala kepuasan pernikahan dan beberapa pertanyaan terbuka sebagai data penunjang. Alat ukur Workplace Romance ini dimodifikasi oleh peneliti berdasarkan alat ukur workplace romance dari Khan, Jianguo, Usman, \& Ahmad (2017) dan Skala Kepuasan Pernikahan berdasarkan aspek-aspek kepuasan pernikahan dari Fowers \& Olson (1993), yaitu : personality issues, communication, conflict resolution, financial management, leisure activities, sexual relationship, children and parenting, family and friends, equalitarian roles, dan religious orientation.

Kedua alat ukur ini menggunakan 5 alternatif jawaban, yaitu: Sangat Setuju (SS), Setuju (S), Kurang Setuju (KS), Tidak Setuju (TS), dan Sangat Tidak Setuju (STS). Koefisien reliabilitas alat ukur workplace romance sebesar 0.748 yang termasuk dalam kategori alat ukur yang memiliki reliabilitas tinggi, sedangkan koefisien reliabilitas alat ukur kepuasan pernikahan sebesar 0.927 yang termasuk dalam kategori alat ukur yang memiliki reliabilitas sangat tinggi.

Pertanyaan terbuka yang diajukan kepada subjek penelitian adalah "jelaskan alasan yang membuat Bapak/Ibu memilih/membawa/mengikuti pasangan untuk sama-sama bekerja di Yayasan X ?", "apakah saudara merasa puas dengan pernikahan saudara? Jelaskan alasannya!"

\section{Teknik Analisis Data}

Analisis data yang digunakan dalam penelitian ini adalah regresi sederhana. Syarat dilakukannya analisis regresi adalah data bersifat interval, maka perlu dikonversi terlebih dahulu dengan menggunakan metode succesive interval. Analisis regresi sederhana juga mensyaratkan adanya uji asumsi klasik berupa uji normalitas dan uji linieritas.

\section{HASIL}

Berikut merupakan gambaran subjek penelitian yang didapatkan dari data demografi yang mencakup jenis kelamin, masa kerja, lama pernikahan, dan status pernikahan.

Tabel 1.

Deskripsi Subjek Penelitian

\begin{tabular}{lll}
\hline \multirow{2}{*}{ Variabel } & Kategori & Jumlah \\
\hline \multirow{2}{*}{ Jenis Kelamin } & Laki-laki & 33 \\
& Perempuan & 39 \\
Masa Kerja & $<5$ tahun & 19 \\
& $5-10$ tahun & 29 \\
& $>10$ tahun & 24 \\
Lama pernikahan & $<5$ tahun & 22 \\
& $5-10$ tahun & 17
\end{tabular}




\begin{tabular}{lll} 
& $11-15$ tahun & 22 \\
& $16-20$ tahun & 9 \\
& $21-25$ tahun & 2 \\
& Bertemu pasangan di Yayasan & 22 \\
Status pernikahan & Mengikuti/membawa pasangan & 50 \\
\hline
\end{tabular}

Tabel 1 menunjukkan bahwa sebagian besar responden berjenis kelamin perempuan, masa kerja sekitar 5 - 10 tahun, lama pernikahan di bawah 5 tahun dan sekitar 11 - 15 tahun, dan status pernikahan yang mengikuti atau mebawa pasangan.

Berikut merupakan gambaran workpalce romance dan kepuasan pernikahan subjek penelitian.

Tabel 2

\begin{tabular}{lll} 
Gambaran Workplace Romance dan Kepuasan Pernikahan \\
\hline \multirow{2}{*}{ Variabel } & Kategori & Jumlah \\
\hline \multirow{2}{*}{ Workplace Romance } & Tinggi & 66 \\
& Cukup Tinggi & 6 \\
Kepuasan Pernikahan & Puas & 39 \\
& Cenderung & 33 \\
& Puas & \\
\hline
\end{tabular}

Data di atas menunjukkan bahwa sebanyak 66 orang responden berada dalam kategori workplace romance yang tinggi, artinya subjek memiliki keinginan yang kuat untuk bertahan dalam hubungan, menjaga hubungan dan memiliki kedekatan dengan pasangannya sesama pegawai Yayasan $\mathrm{X}$ dan 39 orang responden merasa puas dengan pernikahan mereka, artinya subjek merasa puas mengenai kualitas pernikahannya secara menyeluruh.

Tabel 3.

Kategorisasi Workplace Romance dan Kepuasan Pernikahan

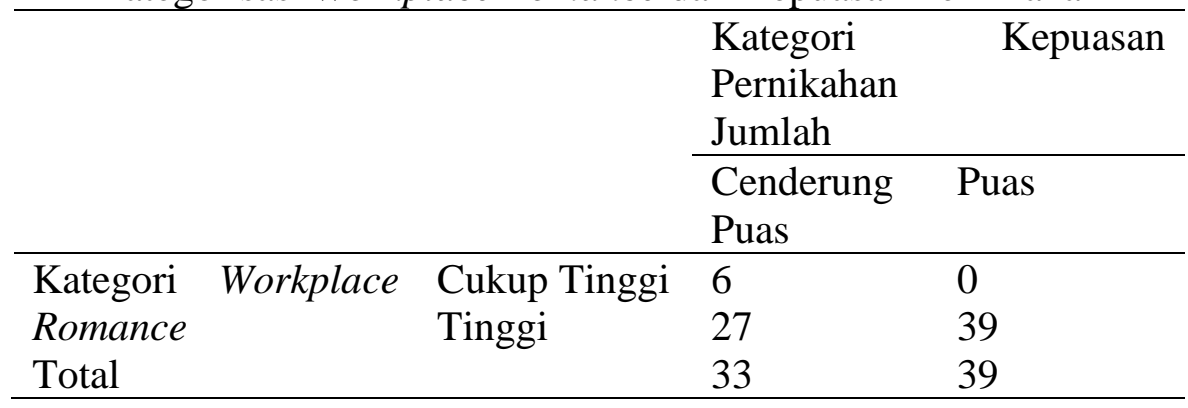

Data di atas menunjukkan bahwa sebanyak 39 orang responden berada dalam kategori workplace romance yang tinggi dan puas dengan pernikahan mereka, sebanyak 27 orang responden berada dalam kategori workplace romance yang tinggi dan cenderung puas dengan pernikahan mereka, sedangkan 6 orang responden lainnya berada dalam kategori workplace romance cenderung tinggi dan cenderung puas dengan pernikahan mereka.

Penjelasan lebih rinci mengenai kontibusi tiap-tiap aspek kepuasan pernikahan pada pegawai Yayasan $\mathrm{X}$ yang memiliki pasangan satu tempat kerja menunjukkan bahwa aspek yang memiliki kontribusi yang besar adalah communication, yaitu sebesar 13,5\%, selanjutnya personality issues sebesar $11,72 \%$, leisure activities sebesar $11,35 \%$, conflict resolution sebesar 10,3\%, sexual relationship sebesar 10,24\%, equalitarian roles sebesar 9,9\%, family 
FAUZIYYAH SHOLEHA TUNNISSA, YUS NUGRAHA, \& ANISSA LESTARI

KADIYONO, Workplace Romance Dan Peranannya Terhadap Kepuasan Pernikahan

Karyawan

and friend sebesar 9,52\%, religious orientation sebesar 9.21\%, financial management sebesar $9,2 \%$, children and parenting sebesar 5,06\%.

Syarat dilakukan analisis regresi sederhana adalah data yang normal dan hubungan linier antar variabel. Uji normalitas pada penelitian ini menggunakan uji One-Sample Kolmogorov-Smirnov. Berikut merupakan hasil perhitungan :

Tabel 4.

Ringkasan Hasil uji One-Sample Kolmogorov-Smirnov

\begin{tabular}{lllll}
\hline Variabel & Signifikansi & $\alpha$ & Kondisi & Simpulan \\
\hline Workplace Romance & 0.173 & 0.05 & $\mathrm{~S}>\alpha$ & Normal \\
Kepuasan Pernikahan & 0.073 & 0.05 & $\mathrm{~S}>\alpha$ & Normal \\
\hline
\end{tabular}

Uji linieritas pada penelitian ini menggunakan Test for Linearity. Berikut merupakan hasil perhitungan :

Tabel 5.

Ringkasan Hasil Test for Linearity

\begin{tabular}{lllll}
\hline Keterangan & Signifikansi & $\alpha$ & Kondisi & Simpulan \\
\hline $\mathrm{KP}^{\mathrm{a}} * \mathrm{WR}^{\mathrm{b}}$ & 0.469 & 0.05 & $\mathrm{~S}>\alpha$ & Linier \\
\hline
\end{tabular}

Keterangan : ${ }^{a}$ Kepuasan Pernikahan; ${ }^{b}$ Workplace Romance

Berdasarkan uji normalitas dan uji linearitas yang telah dilakukan, diketahui bahwa data penelitian berdistribusi normal dan kedua variabel memiliki hubungan yang linear. Oleh karena itu, uji hipotesis dapat dilakukan dengan menggunakan analisis regresi linier sederhana. Berikut merupakan hasil uji regresi linier sederhana.

Tabel 6.

Hasil uji regresi linier sederhana

\begin{tabular}{llllll}
\hline R Square & F & Signifikansi & $\alpha$ & Kondisi & Simpulan \\
\hline 0.246 & 22.101 & 0.000 & 0.05 & $\mathrm{~S}>\alpha$ & Ada pengaruh \\
\hline
\end{tabular}

Berdasarkan uji regresi linier sederhana dapat diketahui bahwa terdapat pengaruh workplace romance terhadap kepuasan pernikahan dapat diketahui dari nilai signifikansi yang lebih kecil dibandingkan dengan alpha. Besarnya pengaruh workplace romance terhadap kepuasan pernikahan sebesar $24.6 \%$, sedangkan sisanya $75.4 \%$ dipengaruhi oleh faktor lain.

Tabel 7.

Persamaan Regresi

\begin{tabular}{lll}
\hline \multirow{2}{*}{ Model } & \multicolumn{2}{l}{ Unstandardized Coefficients } \\
\cline { 2 - 3 } & $\mathrm{B}$ & Std.Error \\
\hline Konstantan & 4,360 & 0.124 \\
Workplace romance & 0.015 & 0.003 \\
\hline
\end{tabular}

Berdasarkan Tabel 7 dapat diketahui bahwa persamaan regresi pengaruh pengaruh workplace romance terhadap kepuasan pernikahan, yaitu : Y $=4.360+0.015 \mathrm{X}$ di mana $\mathrm{Y}$ merupakan Kepuasan Pernikahan dan X adalah Workplace Romance. Nilai 4.360 merupakan 
nilai konstanta yang menunjukkan bahwa jika tidak ada peningkatan workplace romance, maka kepuasan pernikahan akan mencapai 4.360. sedangkan harga $0.015 \mathrm{X}$ menunjukkan bahwa setiap ada peningkatan 1 nilai untuk workplace romance, maka akan ada peningkatan kepuasan pernikahan 0.015 .

Gambaran jawaban responden atas pertanyaan terbuka yang diberikan menunjukkan bahwa alasan responden untuk membawa/mengikuti/memilih pasangan yang bekerja di Yayasan X antara lain sebanyak 35\% responden karena dapat dekat dengan pasangan dan keluarga, 23\% responden dapat memenuhi kebutuhan dari gaji maupun fasilitas yang diberikan Yayasan, 20\% responden merasa mendapatkan pemahaman yang sama dengan pasangan mengenai praktik dan ilmu tentang agama, $8 \%$ responden merasa memiliki kemudahan dalam pengasuhan, $4 \%$ responden merasa memiliki kemudahan dalam manajemen waktu, komunikasi, dapat saling memahami, $2 \%$ responden memiliki kemudahan untuk dapat berbagi tanggung jawab.

Sebanyak 94\% responden merasa puas dengan pernikahannya, 2\% responden merasa cukup puas dan $4 \%$ lainnya merasa belum puas dengan pernikahannya. Adapun beberapa alasan yang menjadi faktor yang memengaruhi kepuasan pernikahan mereka, yaitu sebanyak $22 \%$ responden merasa faktor kepuasan pernikahan mereka karena pribadi pasangan, $21 \%$ responden merasa mereka dapat berbagi tanggung jawab dan pengasuhan dengan pasangan, 19\% responden merasa faktor kepuasan pernikahan mereka karena religiusitas pasangan, $16 \%$ responden merasa memiliki visi yang sama dengan pasangan mengenai pernikahan, $14 \%$ responden merasa kebutuhannya tercukupi, $4 \%$ responden merasa mereka dapat mengelola waktu luang bersama pasangan, $2 \%$ responden merasa karena adanya komunikasi yang efektif dan $2 \%$ responden lainnya karena manajemen konflik yang baik.

Hasil penelitian menyatakan bahwa terdapat pengaruh workplace romance terhadap kepuasan pernikahan. Hal tersebut dapat diartikan semakin tinggi workplace romance makan akan semakin puas dengan pernikahannya. Pernyataan tersebut didukung oleh banyaknya jumlah subjek penelitian yang memiliki workplace romance yang tinggi dan puas akan pernikahannya. Komitmen yang kuat tehadap pasangan akan memengaruhi usaha seseorang untuk memenuhi aspek kepuasan pernikahannya (Hou, Jiang, \& Wang, 2019; Sharma \& Kaur, 2015).

Sebagian besar responden memutuskan untuk terlibat dalam workplace romance agar mereka bisa dekat dengan pasangan dan keluarga. Menurut Furnham (2005) bahwa kehadiran pasangan dapat memberikan dampak positif, yaitu meningkatkan kepuasan dari segala aspek kehidupan, termasuk kepuasan akan hubungan mereka, seperti komunikasi yang semakin mudah. Berdasarkan hasil penelitian bahwa komunikasi merupakan aspek yang mempunyai kontribusi besar dalam kepuasan pernikahan pegawai Yayasan X. Penelitian Chi, Epstein, Fang, Lam, \& Li (2013) menunjukkan bahwa komunikasi memiliki peran penting dalam sebuah hubungan, karena komunikasi yang baik dapat menangani konflik secara efektif, terutama dalam menghadapi perbedaan-perbedaan dalam hubungan. Penelitian du Plooy \& de Beer (2018) juga menunjukkan bahwa yang membuat kepuasan pernikahan menjadi tinggi diantaranya adalah terlibatnya seringnya terlibat dalam komunikasi seperti obrolan ringan dan memberikan pesan kasih sayang baik secara verbal maupun nonverbal, serta memiliki dan menerapkan komunikasi yang efektif.

Aspek berikutnya adalah personality issues. Hal tersebut didukung oleh banyaknya responden yang merasa puas akan pernikahan mereka, dimana faktor pribadi pasangan merupakan faktor yang paling banyak diungkapkan oleh responden. Penelitian Brudek, Steuden, \& Jasik (2018) menunjukkan bahwa kepribadian pasangan memiliki hubungan yang signifikan dengan kepuasan pernikahan, dimana pasangan yang memiliki kepribadian agreeableness merupakan kepribadian yang dapat memprediksi peningkatan kepuasan pernikahan. 
Leisure activities merupakan aspek tertinggi selanjutnya memiliki kontribusi pada kepuasan pernikahan pegawai Yayasan X. Memiliki jam kerja yang sama membuat mereka dapat mengatur waktu bersama pasangan mengenai waktu luang. Penelitian Rhenardo \& Setiawan (2017) menyatakan bahwa komunikasi dan waktu luang bersama dapat meningkatkan kepuasan pernikahan sebanyak 40,2\%. Waktu luang yang dihabiskan bersama pasangan dapat membantu meningkatkan hubungan yang memuaskan (Stebbins, 2017).

Sexual relationship, kedekatan dengan pasangan juga membuat terpenuhinya seksualitas. Frekuensi hubungan seksual secara tidak langsung berpengaruh terhadap kepuasan hubungan (Impett, Muise, \& Rosen, 2020). Banyak peneliti percaya bahwa hubungan seksual adalah faktor penentu terpenting dalam kehidupan pernikahan. Baik atau tidaknya hubungan seksual diyakini dapat menyebabkan perasaan kehilangan, frustrasi, dan kurangnya keamanan dan kemungkinan akan membahayakan kesehatan mental, sehingga mengakibatkan disintegrasi kehidupan keluarga (Tavakol, Nasrabadi, Moghadam, Salehiniya, \& Rezaei, 2017). Hasil dari penelitian Muise, Laughton, Moors, \& Impett (2019) menunjukkan bahwa terpenuhinya kebutuhan seksual dapat memengaruhi kepuasan terhadap hubungan.

Equalitarian roles dan children and parenting, berbagi tanggung jawab dan pengasuhan merupakan alasan yang paling banyak diungkapkan oleh responden sebagai faktor yang mempengaruhi dalam kepuasan pernikahan. Fasilitas tempat tinggal dan tempat penitipan anak yang dekat dengan lingkungan kerja yang diberikan oleh Yayasan, membuat karyawan dapat berbagi peran dengan pasangan dalam pengasuhan. Teori Ekuitas mengakui bahwa pasangan cenderung mengalami kepuasan pernikahan yang lebih besar ketika mereka merasa diri mereka diperlakukan secara adil dalam hal peran dan tanggung jawab menjadi pasangan dan orang tua dalam keluarga (Guerrero, La Valley, \& Farinelli, 2008; Ochsner, 2012). Temuan Kwok, Cheng, Chow, \& Ling (2015) bahwa keterlibatan ayah dalam pengasuhan dapat meringankan tingkat stres ibu, dan meningkatkan kepuasan pernikahan ibu dan mempertahankan pernikahan hubungan. Beberapa studi telah menemukan bahwa kesetaraan yang lebih besar dalam peran gender berhubungan dengan kepuasan pernikahan yang lebih tinggi bahkan dalam budaya tradisional (Cohen, 2011).

Family and friend, bagaimana interaksi sosial dan pertemanan berhubungan dengan tingkat kepuasan pernikahan (Anahita, Sadat, Fini, Hamidreza, \& Neda, 2016) mengenal lingkungan pertemanan pasangan di tempat kerja maupun di rumah, membuat responden merasa lebih tenang dan dapat menumbuhkan rasa saling percaya satu sama lain, karena menurut pertemanan lintas-gender dipandang sebagai suatu bahaya bagi pernikahan (HaavioMannila, 1988).

Religious orientation. Religiusitas pasangan juga memiliki peran penting dalam meningkatkan kepuasan pernikahan, dimana responden mengungkapkan religiusitas sebagai hal yang penting dalam pernikahan. Program rutin mengenai keislaman yang diberikan Yayasan bagi para karyawannya, membuat mereka memiliki pemahaman yang sama dengan pasangan mengenai ilmu agama. Komitmen dalam beragama dan praktik keagamaan sangat penting untuk kehidupan pernikahan yang bahagia. Hal tersebut juga dapat memperkuat dan meningkatkan kepuasan pernikahan (Aman, Abbas, Nurunnabi, \& Bano, 2019; Fard, Shahabi, \& Zardkhaneh, 2013; J. R. Olson, Marshall, Goddard, \& Schramm, 2014).

Financial management. Sama-sama memiliki pendapatan dan mendapatkan fasilitas, seperti rumah dinas, makan, dan sebagainya, membuat responden lebih mudah dalam manajemen keuangan. Menurut Staton (2010) bahwa stabilitas keuangan memiliki peran penting dalam pernikahan, karena hal tersebut berdampak pada kesehatan keluarga, sehingga permasalahan ini perlu diperhatikan. Perilaku dan persepsi tentang seberapa baik pengeloaan keuangan, serta masalah keuangan dan besarnya masalah keuangan berhubungan signifikan 
dengan kepuasan pernikahan (Archuleta, Britt, Tonn, \& Grable, 2011; J. P. Dew, 2016; J. Dew \& Xiao, 2013; Kerkmann, Lee, Lown, \& Allgood, 2000).

Hal-hal di atas membuat workplace romance berpengaruh terhadap kepuasan pernikahan sebesar 24,6\%, sedangkan sisanya $75.4 \%$ dipengaruhi oleh faktor lain, seperti karakteristik pribadi (usia, gender, tingkat pendidikan,lama pernikahan, jumlah anak, jumlah anak yang dibesarkan,status ekonomi, religiusitas, afiliasi keagamaan, budaya (Sorokowski et al., 2017), kelekatan, keintiman, komunikasi, kecerdasan emosi, kesehatan pribadi, pengorbanan (Tavakol et al., 2017).

\section{KESIMPULAN}

Berdasarkan hasil penelitian maka dapat ditarik kesimpulan bahwa workplace romance berpengaruh terhadap kepuasan pernikahan pada karyawan di Yayasan X. Hasil penelitian juga menunjukkan bahwa workplace romance sebagian besar karyawan di Yayasan berada pada kategori tinggi dan puas akan pernikahan mereka.Keterbatasan dalam penelitian ini adalah dalam terfokus pada satu organisasi saja yaitu Yayasan $\mathrm{X}$, sedangkan pengaruh workplace romance terhadap kepuasan pernikahan dapat berbeda di organisasi atau perusahaan lain, bergantung pada kebijakan setiap organisasi atau perusahaan mengenai workplace romance. Penelitian ini juga hanya terfokus pada subjek yang sudah menikah saja, sedangkan di organisasi atau perusahaan lain, mungkin terdapat workplace romance dalam konteks pacaran. Bagi peneliti lainnya yang memiliki ketertarikan untuk mendalami pengaruh workplace romance terhadap kepuasan pernikahan, dapat melakukan penelitian lanjutan dengan aspek-aspek kepuasan hubungan dalam konteks yang lebih luas seperti pacaran. Peneliti selanjutnya juga dapat melakukan penelitian lanjutan mengenai workplace romance terhadap sikap organisasi yang di mediasi oleh kepuasan hubungan.

\section{DAFTAR PUSTAKA}

Abele, A. E., \& Volmer, J. (2011). Dual-Career Couples: Specific Challenges for Work-Life Integration. In S. Kaiser, D. R. Eikhof, M. J. Ringlstetter, \& M. P. e Cunha (Eds.), Creating Balance?!: International Perspectives on the Work-Life Integration of Professionals (pp. 173-189). https://doi.org/10.1007/978-3-642-16199-5_10

Ahmed, K. A. (2016). Marital Satisfaction as a Predictor of Job Commitment of Nurses in Osogbo, Osun State. Redeemer's University.

Aman, J., Abbas, J., Nurunnabi, M., \& Bano, S. (2019). The Relationship of Religiosity and Marital Satisfaction: The Role of Religious Commitment and Practices on Marital Satisfaction Among Pakistani Respondents. Behavioral Sciences, 9(3), 30. https://doi.org/10.3390/bs9030030

Anahita, T. B., Sadat, I. A. F., Fini, I. A., Hamidreza, G., \& Neda, M. A. (2016). The Marital Satisfaction and its Relative Factors among Older Adults. Nursing \& Care Open Access Journal, 1(4). https://doi.org/10.15406/ncoaj.2016.01.00018

Archuleta, K. L., Britt, S. L., Tonn, T. J., \& Grable, J. E. (2011). Financial satisfaction and financial stressors in marital satisfaction. Psychological Reports, 108(2), 563-576. https://doi.org/10.2466/07.21.PR0.108.2.563-576

Berlato, H., \& Correa, K. (2017). A Reformulation of the Dual Career Conceptual Model for Analysis in an Organizational Scope: Revealing new Aspects. Brazilian Business Review, 14(1), 225-246. https://doi.org/10.15728/bbr.2017.14.2.5

Brudek, P., Steuden, S., \& Jasik, I. (2018). Personality traits as predictors of marital satisfaction among older couples. Psychoterapia, 185(2), 5-20.

Burleson, M. H., Trevathan, W. R., \& Todd, M. (2007). In the mood for love or vice versa? 
Exploring the relations among sexual activity, physical affection, affect, and stress in the daily lives of mid-aged women. Archives of Sexual Behavior, 36(3), 357-368. https://doi.org/10.1007/s10508-006-9071-1

Castañeda, D. (2016). Romantic Relationships at Work: Coming into Their Own. In M. F. Karsten (Ed.), Gender, Race, and Ethnicity in the Workplace: Emerging Issues and Enduring Challenges (pp. 85-104). California: Praeger.

Chi, P., Epstein, N. B., Fang, X., Lam, D. O. B., \& Li, X. (2013). Similarity of relationship standards, couple communication patterns, and marital satisfaction among chinese couples. Journal of Family Psychology, 27(5), 806-816. https://doi.org/10.1037/a0034113

Cohen, L. J. (2011). The Handy Psychology Answer Book. In Choice Reviews Online (Vol. 48). Detroit: Visible Ink Press.

Debrot, A., Schoebi, D., Perrez, M., \& Horn, A. B. (2013). Touch as an Interpersonal Emotion Regulation Process in Couples' Daily Lives: The Mediating Role of Psychological Intimacy. Personality and Social Psychology Bulletin, 39(10), 13731385. https://doi.org/10.1177/0146167213497592

Dew, J. P. (2016). Revisiting Financial Issues and Marriage. In J. J. Xiao (Ed.), Handbook of Consumer Finance Research (Second Edi, pp. 281-290). https://doi.org/10.1007/978-3319-28887-1

Dew, J., \& Xiao, J. J. (2013). Financial Declines, Financial Behaviors, and Relationship Happiness during The 2007 - 2009 Recession. Journal of Financial Therapy, 4(1). https://doi.org/10.4148/jft.v4i1.1723

du Plooy, K., \& de Beer, R. (2018). Effective interactions: Communication and high levels of marital satisfaction. Journal of Psychology in Africa, 28(2), 161-167. https://doi.org/10.1080/14330237.2018.1435041

Fard, M. K., Shahabi, R., \& Zardkhaneh, S. A. (2013). Religiosity and Marital Satisfaction. In K. Maree (Ed.), Procedia - Social and Behavioral Sciences (pp. 307 - 311). https://doi.org/10.1016/j.sbspro.2013.06.266

Fowers, B. J., \& Olson, D. H. (1993). ENRICH Marital Satisfaction Scale: A brief research and clinical tool. Journal of Family Psychology, 7(2), 176-185. https://doi.org/10.1037/0893-3200.7.2.176

Furnham, A. (2005). THE PEOPLE BUSINESS : Psychological reflections on management. https://doi.org/10.1057/9780230510098

Guerrero, L. K., La Valley, A. G., \& Farinelli, L. (2008). The experience and expression of anger, guilt, and sadness in marriage: An equity theory explanation. Journal of Social and Personal Relationships, 25(5), 699-724. https://doi.org/10.1177/0265407508093786

Haavio-Mannila, E. (1988). Cross-Gender Relationships at Work and at Home Through the Family Life Cycle. In S. K. Steinmetz (Ed.), Family and Support Systems Across The Life Span (pp. 197-212). https://doi.org/10.1007/978-1-4899-2106-2

Hou, Y., Jiang, F., \& Wang, X. (2019). Marital commitment, communication and marital satisfaction: An analysis based on actor-partner interdependence model. International Journal of Psychology, 54(3), 369-376. https://doi.org/10.1002/ijop.12473

Impett, E. A., Muise, A., \& Rosen, N. O. (2020). Sex as Relationship Maintenance. In B. G. Ogolsky \& J. K. Monk (Eds.), Relationship Maintenance: Theory, Process, and Context (pp. 215-239). United Kingdom: Cambridge University Press.

Karsten, M. F. (2006). Management, gender, and race in the 21st century. United States: University Press of America.

Kerkmann, B. C., Lee, T. R., Lown, J. M., \& Allgood, S. M. (2000). Financial management, 
financial problems and marital satisfaction among recently married university students. Journal of Financial Counseling and Planning, 11(2), 55-65.

Khan, M. A. S., Jianguo, D., Abdul Hameed, A., Mushtaq, T., \& Usman, M. (2018). Affective commitment foci as parallel mediators of the relationship between workplace romance and employee job performance: a cross-cultural comparison of the People\&rsquo;s Republic of China and Pakistan. Psychology Research and Behavior Management, Volume 11(January 2019), 267-278. https://doi.org/10.2147/PRBM.S168542

Khan, M. A. S., Jianguo, D., Usman, M., \& Ahmad, M. I. (2017). Moderated Mediation Model of Interrelations between Workplace Romance, Wellbeing, and Employee Performance. Frontiers in Psychology, 8(DEC), 1-13. https://doi.org/10.3389/fpsyg.2017.02158

Koole, S. L., Tjew A Sin, M., \& Schneider, I. K. (2014). Embodied Terror Management: Interpersonal Touch Alleviates Existential Concerns Among Individuals With Low SelfEsteem. Psychological Science, 25(1), 30-37. https://doi.org/10.1177/0956797613483478

Kwok, S. Y. C. L., Cheng, L., Chow, B. W. Y., \& Ling, C. C. Y. (2015). The Spillover Effect of Parenting on Marital Satisfaction Among Chinese Mothers. Journal of Child and Family Studies, 24(3), 772-783. https://doi.org/10.1007/s10826-013-9888-x

Mainiero, L. A. (1989). Office Romance: Love, Power and Sex in The Workplace. New York: Macmillan Publishing Company.

Muise, A., Laughton, A. K., Moors, A., \& Impett, E. A. (2019). Sexual need fulfillment and satisfaction in consensually nonmonogamous relationships. Journal of Social and Personal Relationships, 36(7), 1917-1938. https://doi.org/10.1177/0265407518774638

Ochsner, T. J. (2012). The Impact of Dual-Career Marriage on Role Conflict and Marital Satisfaction (University of Portland). Retrieved from https://pilotscholars.up.edu/cgi/viewcontent.cgi?article=1073\&context=cst_studpubs

Olson, D. H. ., DeFrain, J., \& Skogrand, L. (2014). Marriages \& Families: Intimacy, Diversity, and Strengths. In McGraw-Hill Education (Eighth edi). https://doi.org/10.1017/CBO9781107415324.004

Olson, J. R., Marshall, J. P., Goddard, H. W., \& Schramm, D. G. (2014). Variations in Predictors of Marital Satisfaction Across More Religious and Less Religious Regions of the United States. Journal of Family Issues, 37(12), 1658-1677. https://doi.org/10.1177/0192513X14560643

Perry-Jenkins, M., Repetti, R. L., \& Crouter, A. C. (2000). Work and family in the 1990s. Journal of Marriage and Family, 62(4), 981-998. https://doi.org/10.1111/j.17413737.2000.00981.x

Pierce, C. A., \& Aguinis, H. (2003). Romantic Relationships in Organizations: A Test of a Model of Formation and Impact Factors. Management Research: Journal of the Iberoamerican Academy of Management, 1(2), 161-169. https://doi.org/10.1108/15365430380000524

Pierce, C. A., Byrne, D., \& Aguinis, H. (1996). Attraction in organizations: A model of workplace romance. Journal of Organizational Behavior, 17(1), 5-32. https://doi.org/10.1002/(SICI)1099-1379(199601)17:1<5::AID-JOB734>3.0.CO;2-E

Powell, G. N. (2011). Women and Men in Management. California: SAGE Publications, Inc.

Quinn, R. E. (1977). Coping with Cupid: The Formation, Impact, and Management of Romantic Relationships in Organizations. Administrative Science Quarterly, 22(1), 30. https://doi.org/10.2307/2391744

Ramteke, S. V. (2015). Study of Effects of Workplace Romance on Individuals (A Study in IT Sector in India). Tata Institute of Social Sciences. 
FAUZIYYAH SHOLEHA TUNNISSA, YUS NUGRAHA, \& ANISSA LESTARI

KADIYONO, Workplace Romance Dan Peranannya Terhadap Kepuasan Pernikahan

Karyawan

Rhenardo, C. A., \& Setiawan, J. L. (2017). Joint Leisure Time , Communication , and Marital Satisfaction among Taxi Drivers. Psychopreneur Journal, 1(2), 106-114.

Rusbult, C. A., Martz, J. M., \& Agnew, C. R. (1998). The Investment Model Scale: Measuring commitment level, satisfaction level, quality of alternatives, and investment size. Personal Relationships, 5(4), 357-387. https://doi.org/10.1111/j.14756811.1998.tb00177.x

Sharma, D., \& Kaur, R. (2015). Role of Love in Relationship Satisfaction. Indian Psychology, 3(1), 2348-5396 (e).

Sias, P. M. (2008). Romantic Workplace Relationships. In Organizing Relationships: Traditional and Emerging Perspectives on Workplace Relationships (1 edition, pp. 125154). California: SAGE Publications, Inc.

Sorokowski, P., Randall, A. K., Groyecka, A., Frackowiak, T., Cantarero, K., Hilpert, P., ... Sorokowska, A. (2017). Marital Satisfaction, Sex, Age, Marriage Duration, Religion, Number of Children, Economic Status, Education, and Collectivistic Values: Data from 33 Countries. Frontiers in Psychology, 8(JUL). https://doi.org/10.3389/fpsyg.2017.01199

Staton, J. (2010). Making the Connection Between Healthy Marriage and Health Outcomes: What the Research Says. In National Healthy Marriage Resource Center Wingspread Making Connections conference.

Stebbins, R. A. (2017). Leisure Activities in Context: A Micro-Macro/Agency-Structure Interpretation of Leisure. Retrieved from http://dx.doi.org/10.1016/j.jsames.2011.03.003\%0Ahttps://doi.org/10.1016/j.gr.2017.08. 001\%0Ahttp://dx.doi.org/10.1016/j.precamres.2014.12.018\%0Ahttp://dx.doi.org/10.101 6/j.precamres.2011.08.005\%0Ahttp://dx.doi.org/10.1080/00206814.2014.902757\%0Aht tp://dx.

Tavakol, Z., Nasrabadi, A. N., Moghadam, Z. B., Salehiniya, H., \& Rezaei, E. (2017). A Review of the Factors Associated with Marital Satisfaction. Galen Medical Journal, 6(3). https://doi.org/10.22086/gmj.v0i0.641

van Steenbergen, E. F., Kluwer, E. S., \& Karney, B. R. (2014). Work-family enrichment, work-family conflict, and marital satisfaction: A dyadic analysis. Journal of Occupational Health Psychology, 19(2), 182-194. https://doi.org/10.1037/a0036011 